DOI https://doi.org/10.15589/znp2019.2(476).12

УДК 504.3.054

\title{
EVALUATION OF TECHNOGENEOUS LOAD ON THE AIR POOL OF MYKOLAIV REGION
}

\section{ОЦІНКА ТЕХНОГЕННОГО НАВАНТАЖЕННЯ НА ПОВІТРЯНИЙ БАСЕЙН МИКОЛАЇВСЬКОЇ ОБЛАСТІ}

\author{
Anhelina V. Chuhai \\ avchugai@ukr.net \\ ORCID: 0000-0002-8091-8430
}

\author{
А. В. Чугай, \\ канд. географ. наук, доцент
}

Odessa State Environmental University, Odessa

Одеський державний екологічний університет, м. Одеса

\begin{abstract}
Purpose. The purpose of the work is to evaluate the technogenic load on the air pool of the Mykolaiv region for a long period (2000-2018). Method. To estimate the technogenic load, the principle of calculation of the technogenic load $\left(M_{T}\right)$ module was applied. Taking into account the principle of determination of $M_{T}$, the assessment of the level of technogenic load on the air basin was performed on the basis of the calculation of the module of technogenic load on the air basin $\left(M_{A B}\right)$, which is defined as the amount of emissions of CL into the atmospheric air in thousand $\mathrm{t} / \mathrm{km}^{2}$ per year. Results. The main pollutants of the region's atmospheric air among stationary sources over the years have been 3 enterprises. By 2011, there is an increase in the total amount of CL emissions with a predominant increase in emissions from mobile sources, and from 2012 a gradual decrease in emissions. In the cities of the region, the maximum volumes of pollutants emissions from stationary sources are noted in Mykolaiv, the minimum - in the Ochakov and Yuzhnoukrainsk cityes. According to the list of pollutants, emissions of nitrogen, methane and carbon monoxide compounds (stationary sources) are dominant in the emission structure. The calculation of the $M_{A B}$ indicator for the Mykolaiv region showed its correspondence to the dynamics of pollutants emissions in the region. An analysis of the dynamics of the change of the $M_{A B}$ for individual cities of the region showed that the level of technogenic load in 2000-2008 in Nikolaev, Voznesensk and Pervomaisk cityes are characterized by close indicators. This indicates that the significant difference and small area of individual cities increases the total load on the air pool. Compared to the indicator of $M_{A B}$ in the region, the level of technogenic load on individual cities is 1-2 orders of magnitude higher. Scientific novelty. The scientific novelty of the work is that for the first time for the Mykolaiv region the estimation of anthropogenic loading on an air pool for the long-term period is made. Practical importance. The practical significance of the work is that its results are the basis for the development of environmental recommendations for reducing the emissions into the atmospheric air of the region, primarily from mobile sources. They can also be introduced into the educational process when teaching certain disciplines of professional training in the specialties 101 "Environmental Science" and 183 "Environmental Protection Technologies".
\end{abstract}

Key words: air pool; pollutant; technogenic load module.

Анотація. Мета. Метою роботи є оцінка техногенного навантаження на повітряний басейн Миколаївської області за багаторічний період (2000-2018рр.). Методика. Для оцінки техногенного навантаження був застосований принцип розрахунку модуля техногенного навантаження $\left(M_{T}\right)$. 3 урахуванням принципу визначення $M_{T}$ було виконано оцінку рівня техногенного навантаження на повітряний басейн на основі розрахунку модуля техногенного навантаження на повітряний басейн $\left(M_{\Pi Б}\right)$, який визначається як обсяг викидів забруднюючих речовин в атмосферне повітря в тисячах т/км² на рік. Результати. Головними забруднювачами атмосферного повітря регіону серед стаціонарних джерел протяггом багатьох років є 3 підприємства. До 2011 р. зазначається збільшення загального обсягу викидів ЗР із переважаючим збільшенням викидів від пересувних джерел, а 3 2012 р. - поступове зменшення обсягів викидів. По містах області максимальні обсяги викидів ЗР від стаціонарних джерел визначаються у місті Миколаїв, мінімальні - у містах Очаків і Южноукраїнськ. За переліком забруднюючих речовин переважаючими у структурі викидів є викиди сполук азоту, метану і оксиду вуглецю (стаціонарні джерела). Розрахунок показника $M_{\Pi ь}$ для Миколаївської області показав його відповідність

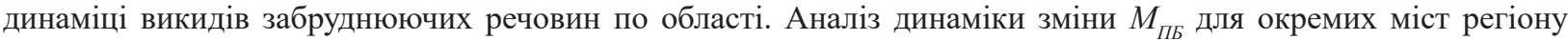
показав, що рівень техногенного навантаження у 2000-2008 р. у містах Миколаїв, Вознесенськ і Первомайськ характеризується близькими показниками. Це свідчить про те, що при суттєвій різниці і незначній площі окре-

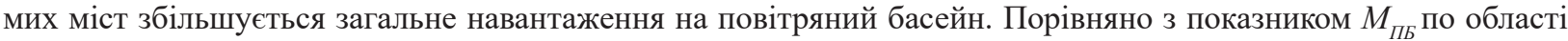
рівень техногенного навантаження на окремі міста на 1-2 порядки вище. Наукова новизна. Наукова новизна 


\section{ТЕХНОЛОГІЇ ЗАХИСТУ НАВКОЛИШНЬОГО СЕРЕДОВИЩА №2ロ 2019}

роботи полягає в тому, що вперше для Миколаївської області виконана оцінка техногенного навантаження на повітряний басейн за багаторічний період. Практична значимість. Практична значимість роботи полягає в тому, що ії результати $є$ основою для розробок природоохоронних рекомендацій щодо зменшення викидів в атмосферне повітря регіону, в першу чергу, від пересувних джерел. Також вони можуть бути впроваджені в навчальний процес під час викладання окремих дисциплін фахової підготовки зі спеціальностей 101 «Екологія» і 183 «Технології захисту навколишнього середовища».

Ключові слова: повітряний басейн; забруднююча речовина; модуль техногенного навантаження.

\section{ПОСТАНОВКА ЗАДАЧІ}

Проблема техногенного забруднення атмосферного повітря регіонів України є особливо гострою. Стан повітряного басейну залежить від впливу стаціонарних (об'єкти промисловості і теплоенергетики), а також пересувних джерел забруднення, 3 яких домінуючим є автомобільний транспорт.

У регіонах Північно-Західного Причорномор'я, до якого входить, в тому числі, Миколаївська область, внесок пересувних джерел у формування загального рівня забруднення атмосфери становить до $80 \%$. Саме тому задача визначення основних джерел забруднення й оцінки техногенного навантаження на повітряний басейн регіону є актуальною для Миколаївської області.

\section{АНАЛІЗ ОСТАННІХ ДОСЛІДЖЕНЬ І ПУБЛІКАЦІЙ}

Питання оцінки якості атмосферного повітря $\mathrm{i}$ рівня антропогенного впливу розглядались у роботах багатьох авторів. По-перше, ці питання є предметом досліджень автора роботи та його співаторів. Так, у роботах [1-3] надано результати оцінки якості атмосферного повітря регіонів Північно-Західного Причорномор'я (ПЗП), в тому числі в м. Миколаїв за багаторічний період. У роботі [4] було виконано оцінку техногенного навантаження на повітряний басейн Миколаївської області за 2012 - 2016 рp., а у роботі [5] узагальнені деякі результати щодо оцінки навантаження на повітряний басейн промислово-міських агломерацій ПЗП.

Деякими авторами виконані комплексні дослідження рівня забруднення атмосфери регіонів України. Наприклад, у роботі [6] виконано загальну оцінку стану забруднення атмосферного повітря за вмістом окремих забруднюючих речовин (ЗР). У роботі [7] проведено класифікацію міст України за рівнем забруднення атмосфери. Розглядався вміст 4 3Р: завислі речовини, оксид вуглецю, діоксид азоту і формальдегід. Так, за вмістом завислих речовин і оксиду вуглецю Миколаїв увійшов до групи міст України 3 допустимим рівнем забруднення атмосфери, за вмістом діоксиду азоту - до групи з підвищеним рівнем, за вмістом формальдегіду - до групи з екстремально високим рівнем. Також, з іншого боку, є дослідження, присвячені оцінці впливу забруднення атмосферного повітря на стан здоров'я населення [8]. За представленими результатами за рівнем впливу Миколаївська область увійшла до безризикової зони. Що стосується антропогенного навантаження, цікавим є дослідження авторів роботи [9]. Представлено результати кластерного аналізу регіонів України за рівнем антропогенного навантаження, в тому числі і за обсягами викидів ЗР. Так, Миколаївська область увійшла до переліку регіонів із низьким рівнем навантаження.

\section{ВІДОКРЕМЛЕННЯ НЕ ВИРІШЕНИХ РАНІШЕ ЧАСТИН ЗАГАЛЬНОЇ ПРОБЛЕМИ}

Як показав аналіз результатів досліджень щодо рівня антропогенного навантаження на Миколаївську область, наявні роботи, присвячені питанням оцінки навантажень загалом на довкілля регіону. Проте оцінка техногенного навантаження на повітряний басейн окремо не виконувалась, за виключенням робіт, виконаних автором.

\section{МЕТА ДОСЛІДЖЕННЯ}

Метою роботи є оцінка техногенного навантаження на повітряний басейн Миколаївської області за багаторічний період (2000-2018рp.). Ця робота $\epsilon$ подовженням досліджень, представлених у роботах [4-5]. Як вихідні дані в роботі використані матеріали Регіональних доповідей про стан навколишнього природного середовища і Екологічних паспортів Миколаївської області $[10$, с. $9 ; 11$, с. $17 ; 12$, с. 6 ; 13 , c. 9,$12 ; 14$, c. 10,$12 ; 15$, c. $8-9,11 ; 16$, c. 10,13$]$.

\section{МЕТОДИ, ОБ'ЄКТ ТА ПРЕДМЕТ ДОСЛІДЖЕННЯ}

Для оцінки техногенного навантаження був застосований принцип розрахунку модуля техногенного навантаження $\left(M_{T}\right)$, який визначається як сума вагових одиниць всіх видів відходів (твердих, рідких, газоподібних) промислових, сільськогосподарських і комунальних об'єктів за часовий проміжок - 1 рік, зарахована до площі адміністративного району або області, в межах якої розташовані ці об'єкти, що вимірюються в тисячах т/км² на рік [17, с. 254]. 3 урахуванням принципу визначення $M_{T}$ було оцінено рівень техногенного навантаження на повітряний басейн на основі розрахунку модуля техногенного навантаження на повітряний басейн $\left(M_{\Pi Б}\right)$, який визначається як обсяг викидів ЗР в атмосферне повітря в тисячах т/км² на рік. Цей підхід був вже реалізований автором раніше. Причому показник $M_{\text {ПБ }}$ можна розраховувати окремо як для стаціонарних, так і для пересувних джерел. 
Об'єктом дослідження є повітряний басейн Миколаївської області, предметом дослідження - техногенне навантаження на повітряний басейн.

\section{ОСНОВНИЙ МАТЕРІАЛ}

Першим етапом роботи був загальний аналіз джерел антропогенного навантаження на атмосферне повітря регіону. Якщо розглядати стаціонарні джерела, то варто зазначити, що за період дослідження перелік основних стаціонарних джерел по області суттєво змінювався. Так, у 2000 р. до них було зараховано 17 підприємств [18, с. 7], у 2005 р. - 14 [19, с. 22-23], у 2010 p. -3 [20, с. 9], у 2015 p. - 13 [21, с. 16] і у 2018 p. 11 підприємств області [16, с. 16]. До цього переліку протягом 2000-2018 рр. постійно входять ПАТ «Югцемент», ТОВ «Миколаївський глиноземний завод», підприємства, що підпорядковані ПАТ «Уктрансгаз». Також в останні роки до цього переліку входять ДП НВКГ «Зоря» - «Машпроект» і ТОВ СП «Нібулон».

На рис. 1 наведено динаміку викидів ЗР в атмосферне повітря Миколаївської області у 2000-2018 pp. Як видно, з 2000 по 2011 рр. зазначено збільшення загального обсягу викидів ЗР з переважаючим збільшенням викидів від пересувних джерел. 32012 р.

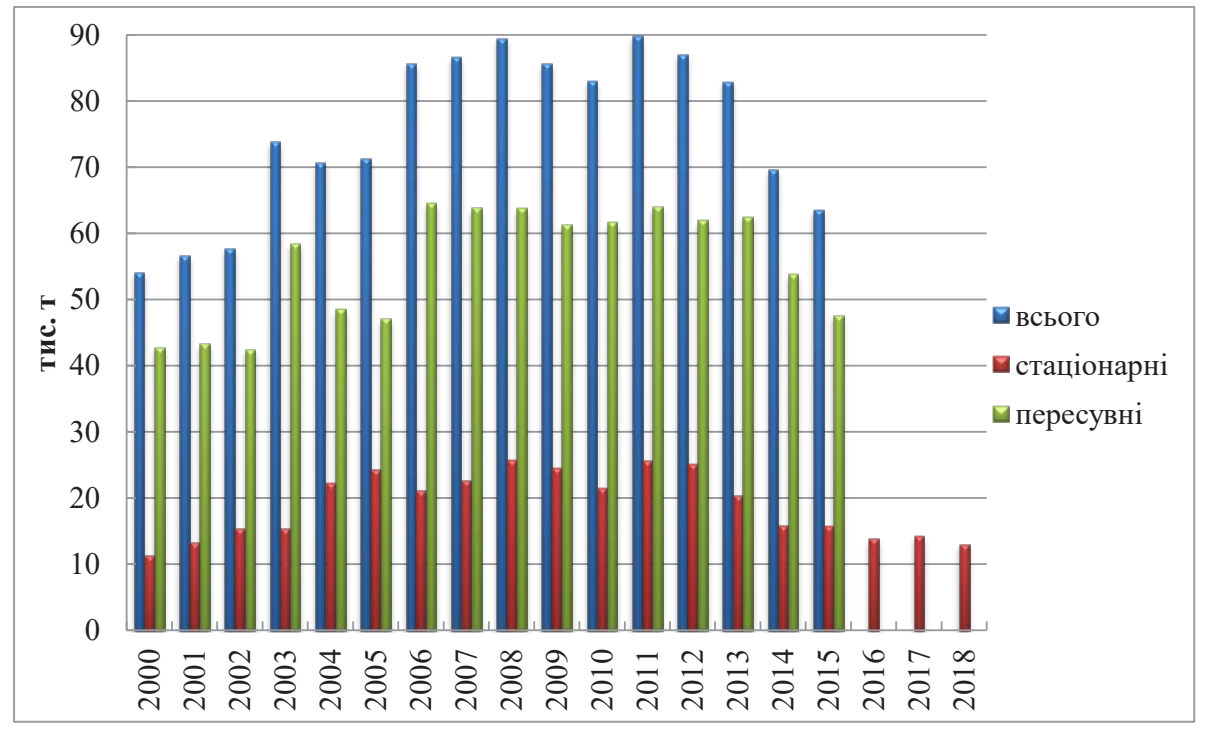

Рис. 1. Динаміка викидів ЗР в атмосферне повітря Миколаївської області у 2000 - 2018 pр.

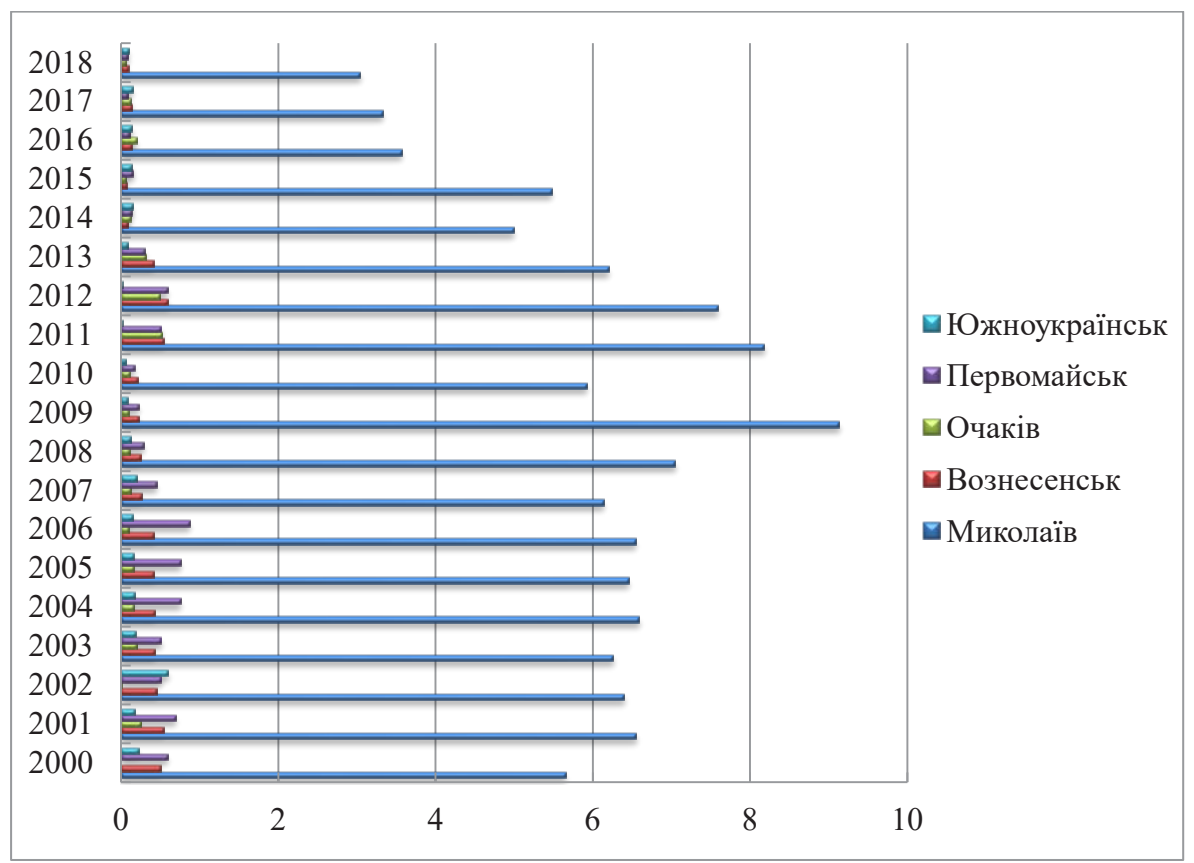

Рис. 2. Динаміка викидів ЗР в атмосферне повітря по містах Миколаївської області у $2000-2018$ pp. 


\section{ТЕХНОЛОГІЇ ЗАХИСТУ НАВКОЛИШНЬОГО СЕРЕДОВИЩА №2 2019}

відзначається поступове зменшення обсягів викидів. Зазначимо, що з 2016 р. в офіційних даних відсутня інформація про обсяги викидів від пересувних джерел, що ускладнює процес аналізу.

Також було проаналізовано динаміку викидів 3Р від стаціонарних джерел по містах області (рис. 2). Максимальні обсяги визначаються в м. Миколаїв, що становить у різні роки близько 50\% від загальних викидів ЗР від стаціонарних джерел по області. Друге місто поділяють міста Первомайськ і Вознесенськ. Мінімальні обсяги викидів ЗР визначаються у містах Очаків і Южноукраїнськ.

Якщо аналізувати обсяги викидів за видами економічної діяльності, то в останні роки найбільші обсяги викидів визначаються на підприємствах енерге- тики та переробної промисловості. Також за переліком ЗР переважають у структурі викидів викиди сполук азоту, метану і оксиду вуглецю (рис. 3).

Розрахунок показника $M_{П Б}$ проводився з урахуванням даних про площу Миколаївської області та окремих населених міст регіону [22]. На рис. 4 наведено

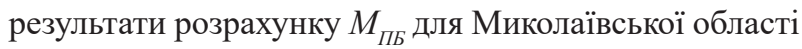
загалом. закономірною є відповідність розподілу показника $M_{\Pi Б}$ динаміці викидів ЗР по області (рис. 1).

На рис. 5 наведено динаміку зміни показника $M_{\Pi b}$ для окремих міст регіону. Аналіз рисунку показує, що рівень техногенного навантаження у 2000-2008 р. у містах Миколаїв, Вознесенськ і Первомайськ характеризується близькими показниками. Тобто при суттєвій різниці обсягів викидів, але через незначну

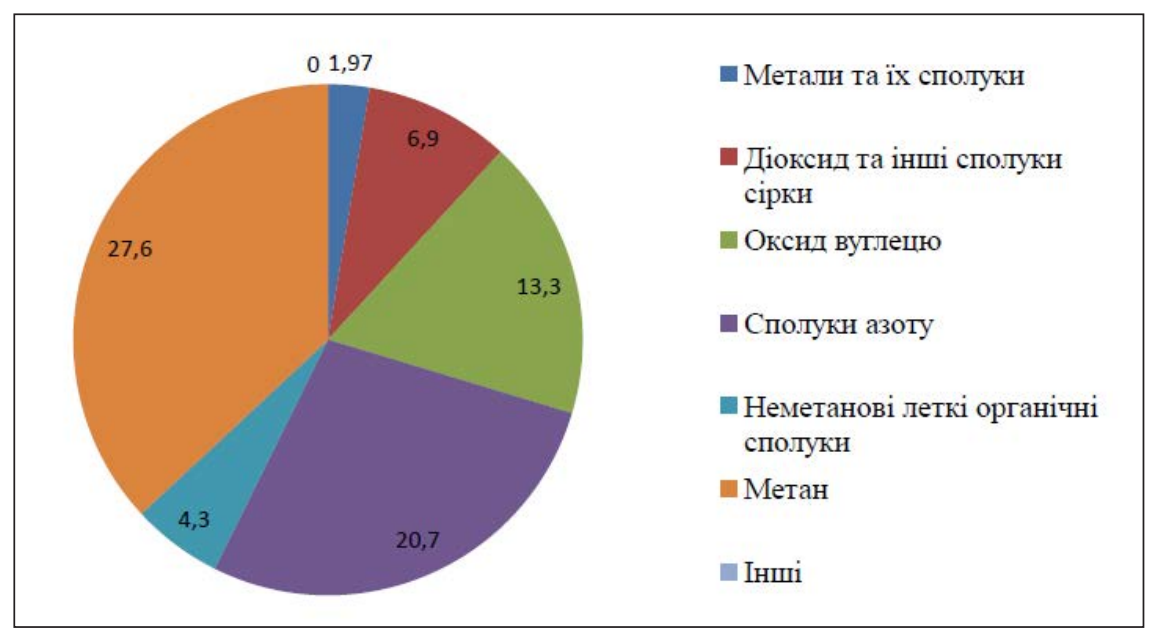

Рис. 3. Структура викидів ЗР в атмосферне повітря від стаціонарних джерел у 2018 р. $[16$, c. 12$]$

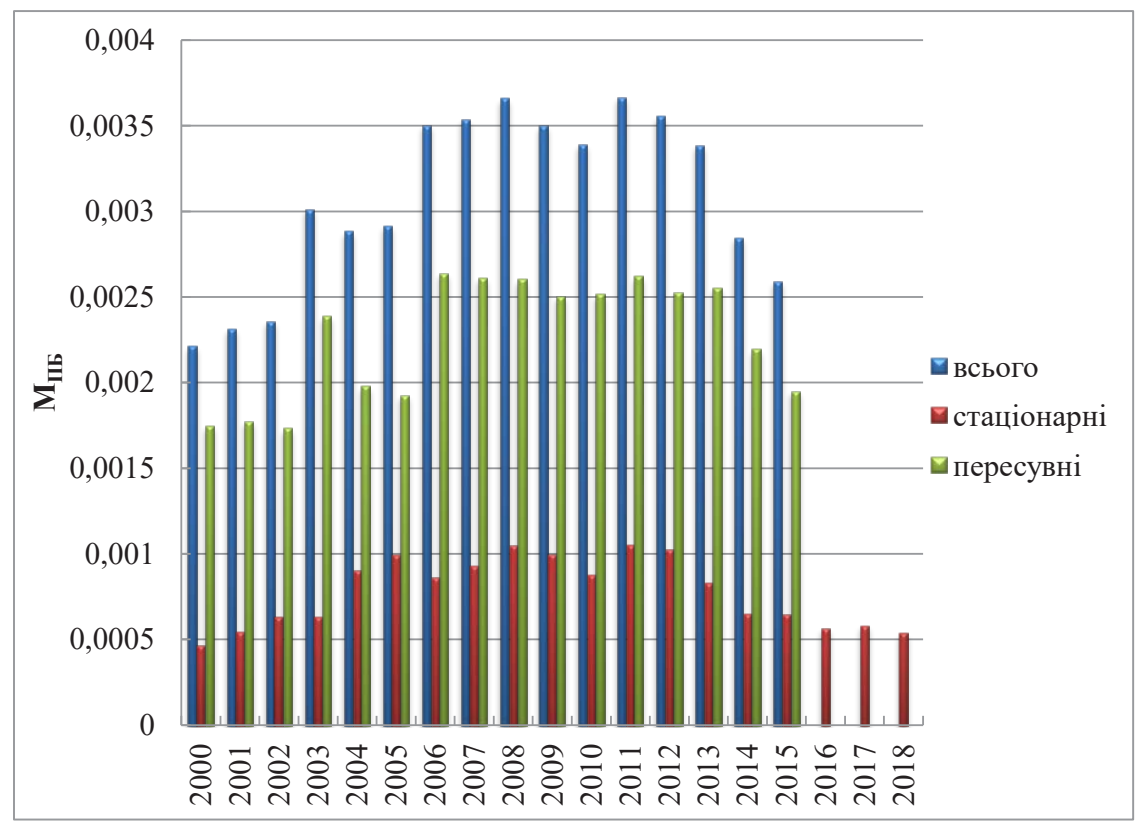

Pис. 4. Динаміка зміни показника $M_{\text {ПБ }}$ для Миколаївської області 
площу окремих міст збільшується навантаження на повітряний басейн. Також близькими є показники навантаження у м. Очаків в окремі роки. 32009 р. зазначається суттєва диференціація показників, оскільки визначалось збільшення викидів у місті Миколаїв i зменшення майже у всіх інших містах. Також варто зазначити, що порівняно з показником $M_{\Pi ь}$ по області загалом рівень техногенного навантаження на окремі міста регіону на 1-2 порядки вище.

\section{ОБГОВОРЕННЯ ОТРИМАНИХ РЕЗУЛЬТАТІВ}

Аналіз попередніх публікацій, присвячених питанням оцінки стану повітряного басейну Миколаївської області, показав, що більшість робіт присвячена питанням оцінки якості атмосферного повітря як за окремими показниками, так і за комплексними підходами. Оцінку антропогенного навантаження проводили також за комплексним підходом з урахуванням впливу на всі природні середовища. Нами було виконано оцінку рівня техногенного навантаження на повітряний басейн Миколаївської області і окремих міст регіону на основі розрахунку модуля техногенного навантаження на повітряний басейн $M_{\Pi Б}$, запропонованого автором. Раніше було виконано відповідну роботу для регіону, проте в цьому дослідженні оцінка виконана за багаторічний період, що дало змогу виявити окремі часові закономірності. Варто зазначити, що відсутність інформації про обсяги викидів від пересувних джерел суттєво звужує можливість оцінки. Так, однією з рекомендацій є обов'язкове включення до офіційних статистичних даних інформацію про обсяги викидів ЗР від пересувних джерел, оскільки це один із головних джерел забруднення атмосферно- го повітря в Миколаївській області, а також у багатьох регіонах України.

\section{ВИСНОВКИ}

У роботі проаналізовано дані щодо викидів ЗР в атмосферне повітря Миколаївської області за багаторічний період (2000-2018 рр.). У результаті можна зробити такі висновки:

1) головними забруднювачами атмосферного повітря регіону серед стаціонарних джерел протягом багатьох років є ПАТ «Югцемент», ТОВ «Миколаївський глиноземний завод», підприємства, що підпорядковані ПАТ «Уктрансгаз»;

2) до 2011 рр. зазначається збільшення загального обсягу викидів ЗР із переважаючим збільшенням викидів від пересувних джерел, а з 2012 р. - поступове зменшення обсягів викидів;

3) по містах області максимальні обсяги викидів ЗР від стаціонарних джерел визначаються у місті Миколаїв (близько 50\% від загальних викидів ЗР по області), мінімальні - в містах Очаків і Южноукраїнськ;

4) за переліком ЗР переважають у структурі викидів викиди сполук азоту, метану і оксиду вуглецю (стаціонарні джерела);

5) розрахунок показника $M_{П ь}$ для Миколаївської області показав його відповідність динаміці викидів ЗР по області;

6) аналіз динаміки зміни $M_{\text {пь }}$ для окремих міст регіону показав, що рівень техногенного навантаження у 2000-2008 р. у містах Миколаїв, Вознесенськ і Первомайськ характеризується близькими показниками. Це свідчить про те, що при суттєвій різниці і

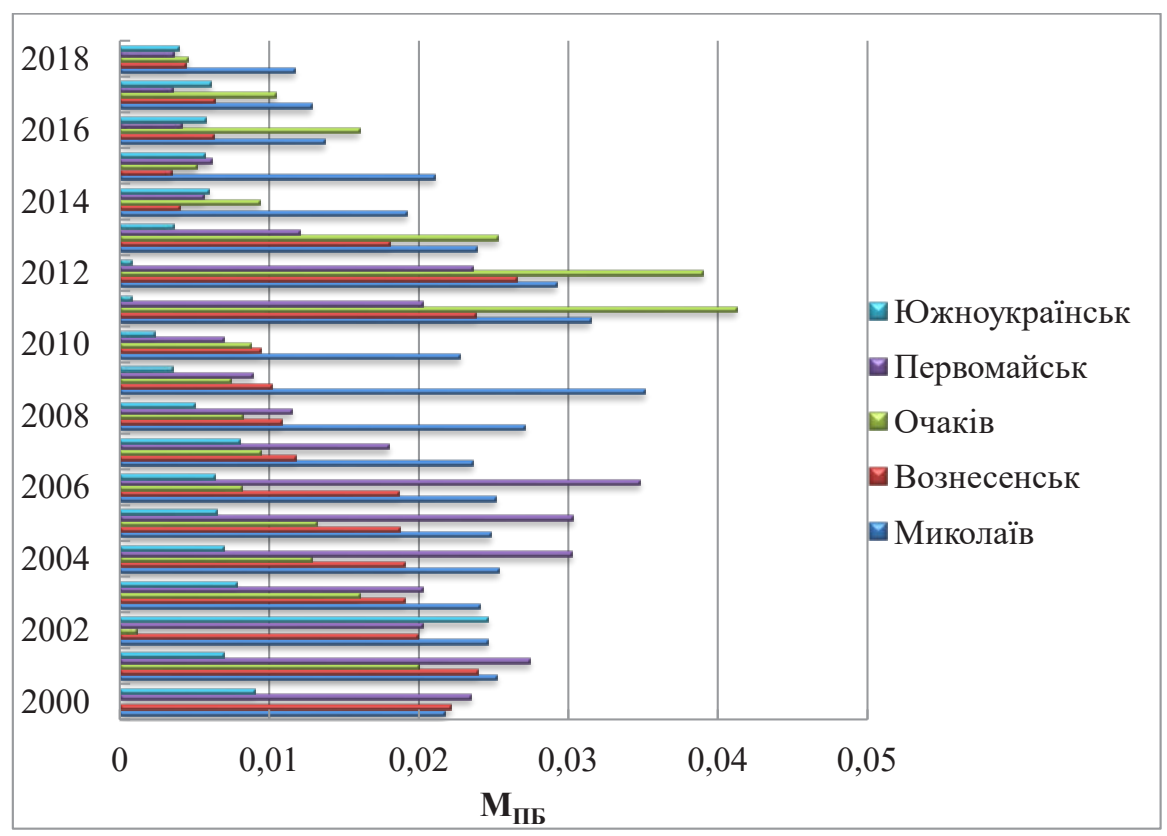

Рис. 5. Динаміка зміни показника $M_{\Pi Б}$ по окремих містах Миколаївської області 


\section{ТЕХНОЛОГІЇ ЗАХИСТУ НАВКОЛИШНЬОГО СЕРЕДОВИЩА №2 2019}

незначній площі окремих міст збільшується загальне навантаження на повітряний басейн. Порівняно $з$ показником $M_{\Pi Б}$ по області рівень техногенного навантаження на окремі міста на 1-2 порядки вище.

Представлені результати дослідження є частиною комплексної роботи, яка присвячена оцінці і порів- няльному аналізу рівня техногенного навантаження на повітряний басейн регіонів ПЗП. Отримані результати $є$ основою для розробок природоохоронних рекомендацій щодо зменшення викидів ЗР в атмосферне повітря регіону, в першу чергу, від пересувних джерел.

\section{REFERENCES}

[1] Chugai, A. (2012). Otsinka zabrudnennia povitrianoho baseinu pivdennykh rehioniv Ukrainy [Assessment of air pollution of the southern regions of Ukraine]. Chyste misto. Chysta rika. Chysta planeta. Chetvertyi mizhnarodnyi ekolohichnyi forum. Kherson, pp. 94-100.

[2] Chugai, A. (2013). Otsinka zabrudnenosti povitrianoho baseinu mista Mykolaiv [Assessment of pollution of the air pool of the Nikolaev city]. Ukrainskyi hidrometeorolohichnyi zhurnal, no. 13. Pp. 10-17.

[3] Chugai, A., Kolisnyk, A., Demianenko, O., Romanenko, S. (2015). Otsinka rivnia zabrudnennia atmosfernoho povitria mist pryberezhnoi zony Pivnichno-Zakhidnoho Prychornomoria [Assessment of the air pollution level of coastal zone cities North Western Black Sea]. Visnyk KhNU im. V.N. Karazina. Ser. «Ekolohiia», vyp. 13. Pp. 91-97.

[4] Chugai, A., Shatokhina, I. (2018). Otsinka tekhnohennoho navantazhennia na povitrianyi basein Mykolaivskoi oblasti [Assessment of technogenic load on the air pool of Mykolaiv region]. Vestnyk Hydromettsentra Chernoho y Azovskoho morei, no. 1(21). Pp. 83-90.

[5] Chugai, A., Safranov, T., Holik, Yu. (2018). Analysis of the state of the air basin of industrial-urban agglomerations in the North-Western Black Sea. International Journal of Engineering \& Technology (UAE), vol. 7, no. 4.8. Pp. 783-789.

[6] Bashtannyk, M., Zhemera, N., Kiptenko, Ye., Kozlenko, T. (2014). Stan zabrudnennia atmosfernoho povitria nad terytoriieiu Ukrainy [Air pollution state the territory of Ukraine]. Naukovi pratsi UkrNDHMI, vyp. 266. Pp. 70-93.

[7] Iatsenko, Yu., Shevchenko, O., Snizhko, S. (2017). Klasyfikatsiia mist Ukrainy za rivnem zabrudnennia atmosfernoho povitria [Classification of the city of Ukraine on the level of atmospheric air pollution]. Visnyk KNU im. Tarasa Shevchenka. Seriia: Heohrafiia, no. 3 (68) / 4 (69). Pp. 25-30.

[8] Tarasova, V. (2013). Vplyv zabrudnennia atmosfernoho povitria na stan zdorovia naselennia [The impact of air pollution on the health of the population]. Ahrosvit, no. 16. Pp. 24-28.

[9] Baluieva, O., Chynkuliak, N. (2013). Klasternyi analiz terytorii Ukrainy za pokaznykamy antropohennykh navantazhen na navkolyshnie pryrodne seredovyshche [Cluster analyses of the Ukrainian territories according to the indices of the anthropogenic loads on the natural environment]. Efektyvna ekonomika, no. 12. Retrieved from: http://www.economy. nayka.com.ua/ op $=1 \& z=2574$.

[10] Natsionalna dopovid pro stan navkolyshnoho pryrodnoho seredovyshcha v Mykolaivskii oblasti v 2002 rotsi (2003) [National report on the state of the environment in the Mykolaiv region in 2002]. Mykolaiv [in Ukraine].

[11] Natsionalna dopovid pro stan navkolyshnoho pryrodnoho seredovyshcha v Mykolaivskii oblasti v 2004 rotsi (2005) [National report on the state of the environment in the Mykolaiv region in 2004]. Mykolaiv [in Ukraine].

[12] Ekolohichnyi pasport rehionu za 2005 rik. Mykolaivska oblast (2006) [Ecological passport of the region for 2005. Mykolaiv region]. Mykolaiv [in Ukraine].

[13] Rehionalna dopovid pro stan navkolyshnoho pryrodnoho seredovyshcha v Mykolaivskii oblasti u 2008 rotsi (2009) [Regional report on the state of the environment in Mykolaiv region in 2008]. Mykolaiv [in Ukraine].

[14] Rehionalna dopovid pro stan navkolyshnoho pryrodnoho seredovyshcha v Mykolaivskii oblasti u 2013 rotsi (2014) [Regional report on the state of the environment in Mykolaiv region in 2013]. Mykolaiv [in Ukraine].

[15] Rehionalna dopovid pro stan navkolyshnoho pryrodnoho seredovyshcha v Mykolaivskii oblasti u 2017 rotsi (2018) [Regional report on the state of the environment in Mykolaiv region in 2017]. Mykolaiv [in Ukraine].

[16] Rehionalna dopovid pro stan navkolyshnoho pryrodnoho seredovyshcha v Mykolaivskii oblasti u 2018 rotsi (2019) [Regional report on the state of the environment in Mykolaiv region in 2018]. Mykolaiv [in Ukraine].

[17] Adamenko, O. M., Rudko, H. I. (1998). Ekolohichna heolohiia [Environmental geology]. Kyiv: Manuskrypt [in Ukraine].

[18] Natsionalna dopovid pro stan navkolyshnoho pryrodnoho seredovyshcha v Mykolaivskii oblasti v 2000 rotsi (2001) [National report on the state of the environment in the Mykolaiv region in 2000]. Mykolaiv [in Ukraine].

[19] Natsionalna dopovid pro stan navkolyshnoho pryrodnoho seredovyshcha v Mykolaivskii oblasti v 2005 rotsi (2006) [National report on the state of the environment in the Mykolaiv region in 2000]. Mykolaiv [in Ukraine].

[20] Ekolohichnyi pasport za 2010 rik. Mykolaivska oblast (2010) [Ecological passport of the region for 2010. Mykolaiv. Mykolaiv [in Ukraine].

[21] Rehionalna dopovid pro stan navkolyshnoho pryrodnoho seredovyshcha v Mykolaivskii oblasti u 2015 rotsi (2016) [Regional report on the state of the environment in Mykolaiv region in 2015]. Mykolaiv [in Ukraine].

[22] Administratyvnyi ustrii Mykolaivskoi oblasti (2017) [Administrative device Mykolaiv region]. Retrieved from: https:// uk.wikipedia.org/wiki/. 


\section{СПИСОК ВИКОРИСТАНОЇ ЛІТЕРАТУРИ}

[1] Чугай, А. В. (2012). Оцінка забруднення повітряного басейну південних регіонів України. Чисте місто. Чиста ріка. Чиста планета. Четвертий міжнародний екологічний форум, 94-100.

[2] Чугай, А. В. (2013). Оцінка забрудненості повітряного басейну міста Миколаїв. Український гідрометеорологічний журнал, № 13, с. 10 - 17.

[3] Чугай, А. В., Колісник, А. В., Демяненко, О. В., Романенко, С. Е. (2015). Оцінка рівня забруднення атмосферного повітря міст прибережної зони Північно-Західного Причорномор'я. Вісник ХНУ ім. В.Н. Каразіна, сер. «Екологія». Вип. 13. С. 91-97.

[4] Чугай, А. В., Шатохіна, I. В. (2018). Оцінка техногенного навантаження на повітряний басейн Миколаївської області. Вестник Гидрометиентра Черного и Азовского морей. № 1(21). С. 83-90.

[5] Chugai, A., Safranov, T., Holik, Yu. (2018). Analysis of the state of the air basin of industrial-urban agglomerations in the North-Western Black Sea. International Journal of Engineering \& Technology (UAE), vol. 7, no. 4.8. Pp. 783-789.

[6] Баштанник, М. П., Жемера, Н. С., Кіптенко, Є. М., Козленко, Т. В. (2014). Стан забруднення атмосферного повітря над територією України. Наукові пращі УкрНДГМІ. Вип. 266. С. 70-93.

[7] Яценко, Ю., Шевченко, О., Сніжко, С. (2017). Класифікація міст України за рівнем забруднення атмосферного повітря. Вісник КНУ ім. Тараса Шевченка, серія: Географія. № 3 (68) / 4 (69). С. 25-30.

[8] Тарасова, В. В. (2013). Вплив забруднення атмосферного повітря на стан здоров’я населення. Агросвіт. № 16. C. $24-28$.

[9] Балуєва, О. В., Чинкуляк, Н. М. (2013). Кластерний аналіз територій України за показниками антропогенних навантажень на навколишнє природне середовище. Ефективна економіка. № 12. URL: http://www.economy.nayka.com. ua/?op=1\&z=2574.

[10] Національна доповідь про стан навколишнього природного середовища в Миколаївській області в 2002 році. (2003). Миколаїв. 153 с

[11] Національна доповідь про стан навколишнього природного середовища в Миколаївській області в 2004 році. (2005). Миколаїв. 208 с.

[12] Екологічний паспорт регіону за 2005 рік. Миколаївська область. (2006). Миколаїв. 67 с.

[13] Регіональна доповідь про стан навколишнього природного середовища в Миколаївській області у 2008 році. (2009). Миколаїв. 186 с.

[14] Регіональна доповідь про стан навколишнього природного середовища в Миколаївській області у 2013 році. (2014). Миколаїв. $211 \mathrm{c.}$

[15] Регіональна доповідь про стан навколишнього природного середовища в Миколаївській області у 2017 році. (2018) Миколаїв. 199 с.

[16] Регіональна доповідь про стан навколишнього природного середовища в Миколаївській області у 2018 році. (2019). Миколаїв. $175 \mathrm{c}$.

[17] Адаменко, О. М., Рудько, Г. І. (1998). Екологічна геологія. Київ : Манускрипт. 348 с.

[18] Національна доповідь про стан навколишнього природного середовища в Миколаївській області в 2000 році. (2001). Миколаїв. $138 \mathrm{c}$

[19] Національна доповідь про стан навколишнього природного середовища в Миколаївській області в 2005 році. (2006). Миколаїв. 188 с.

[20] Екологічний паспорт за 2010 рік. Миколаївська область. (2010). Миколаїв. 98 с.

[21] Регіональна доповідь про стан навколишнього природного середовища в Миколаївській області у 2015 році. (2016). Миколаїв. 228 с.

[22] Адміністративний_устрій_Миколаївської_області. URL: https://uk.wikipedia.org/wiki/. 